\title{
Variation occurring after natural and in vitro multiplication of early Mediterranean cultivars of globe artichoke (Cynara scolymus L)
}

\author{
P Pécaut ${ }^{\star}$, F Martin \\ INRA, Station d'Amélioration des Plantes Maraîchères, F84140 Montfavet, France
}

(Received 16 July 1993; accepted 5 October 1993)

\begin{abstract}
Summary - This study describes 3 variants: pastel, bull and pastel-bull. They appear after natural and in vitro multiplication of early Mediterranean cultivars of the globe artichoke. The rates of their occurrence were evaluated in Violet de Provence and in some other early cultivars. During micropropagation, the frequency of the pastel plants rose when the subculture number increased, sometimes reaching $100 \%$. As these late bolting plants are undesirable, the practical use of micropropagation is restricted. Analysis of the nature of these variants showed that the bull variant is a tetraploid form issued from the normal type. The pastel-bull variant is a diploid-tetraploid chimeral form issued from the pastel type. The differences between the pastel and the normal type have not been explained. Their seed progenies were alike, with the deeply divided leaves of the pastel type. The entire leaf shape, which is a specific characteristic of the normal type of the early Mediterranean cultivars, was not transmitted by seed.
\end{abstract}

\section{Cynara scolymus / in vitro culture / somaclonal variation / tetraploid / variant}

Résumé - Variation dans les cultivars précoces d'artichaut (Cynara scolymus $\mathrm{L}$ ) après multiplication naturelle et in vitro. Cette étude décrit 3 variants pastel, bull et pastel-bull qui apparaissent après multiplication naturelle ou multiplication in vitro chez les cultivars d'artichaut appartenant au groupe précoce méditerranéen. Les fréquences de leur apparition ont été évaluées pour le cultivar Violet de Provence et quelques autres cultivars précoces. Par comparaison au type normal, le variant pastel est plus tardif et ses feuilles sont plus profondément divisées ; les variants bull et pastel-bull ont des capitules plus globuleux, le premier étant de même précocité et ayant des feuilles plus entières, le second étant plus tardif et ayant des feuilles plus profondément divisées. Ces variants se sont maintenus stables après multiplication par boutures au champ. La multiplication in vitro a favorisé surtout le variant pastel, dont la fréquence s'est accrue avec le nombre de subcultures, en atteignant parfois $100 \%$. Cette absence de conformité restreint l'utilisation pratique de la multiplication in vitro. L'analyse de la nature des variants a montré que le variant bull est une forme tétraplö̈de issue du type normal tandis que le variant pastel-bull est une chimère diploïdetétraploïde issue du type pastel, les racines du variant pastel-bull étant diploïdes et les parties aériennes étant en majorité tétraploïdes. La nature des différences entre le type pastel et le type normal n'a pas été déterminée. Les descendances par autofécondation de ces 2 types ont paru identiques, avec des feuilles divisées de type pastel. La faible découpure des feuilles, qui est un des caractères spécifiques du type normal des cultivars précoces méditerranéens, n'a pas été transmise par voie sexuée.

\section{Cynara scolymus / culture in vitro / variation somaclonale / tétraploïde / variant}

\section{INTRODUCTION}

Production of healthy globe artichoke plants using in vitro multiplication encounters a specific difficulty in the case of early Mediterranean cultivars. Such a multiplication tends to be untrue to type, mainly leading to late bolting plants with more deeply divided leaves. This variation, which occurs after micropropagation, was observed in the Violet de Provence cultivar (Pécaut, 1985) and was confirmed in other early cultivars, Catanese (Rossi and De Paoli, 1990), Niscemese, Liscio sardo prococissimo and Tudela (Pécaut and Martin, 1992). On the contrary, the same micropropagation techniques produce

\footnotetext{
${ }^{*}$ Correspondence and reprints
} 
true-to-type multiplication in later cultivars used for spring production, such as Romanesco (Saccardo and Ancora, 1984), Blanc hyérois and Camus de Bretagne (Pécaut, 1985).

Two of the 3 variants occurring after in vitro culture were found identical to the "mutations" arising spontaneously from natural multiplication by offshoots (Pécaut, 1991). These "mutations" have been described and called "pastel" and "bull" by Pochard et al (1969) who have indicated that about 1 per 1000 Violet de Provence plants provide untrue-to-type shoots. Compared with the normal type, the pastel type is distinguished by its lateness and its deeply divided leaves. The bull type produces globular heads and more entire leaves. The third in vitro variant with globular heads and deeply divided leaves, was called "pastel-bull" as it combines features of both pastel and bull variants (Pécaut and Martin, 1992) and looks like a variant mentioned by Bigot and Foury (1984).

The frequency of the pastel variant among in vitro propagated plants increases with the subculture number and can reach $100 \%$ (Pécaut and Martin, 1992).

This phenomenon is only observed among cultivars belonging to the early Mediterranean group (Pécaut and Martin, 1992). Cultivars of this group possess a set of specific characteristics. Firstly, their earliness makes them the only cultivars presently grown for autumn, winter and early spring production. Secondly, they manifest a large heteroblasty in the rosette; entire first leaves are followed by more and more deeply divided leaves. Thirdly, they present the peculiarity that is the object of this study, ie the occurrence of the above-mentioned variant forms.

The first objective of this work was to describe the 3 variants that were observed after natural and in vitro multiplication. The frequencies of occurrence of the variants during multiplication were then studied. Finally, the nature of the variants was investigated.

\section{MATERIALS AND METHODS}

\section{Cultivars}

A collection of 10 cultivars belonging to the early Mediterranean group was observed for about $10 \mathrm{yr}$, with 12 plants for each cultivar. This collection was replanted every 2-3 years with offshoots taken from the previous plants. There were the French cultivars Escarot, Violet de Corse, Violet du Gapeau, Violet de Provence clone INRA VP 45 (Foury et al, 1968), the Italian culti- vars Liscio sardo precocissimo, Masedu, Niscemese, Spinoso sardo, the Spanish cultivar Tuleda D obtained by clonal selection in Blanca di Espana (Trigo Colina, 1981), and the Turkish cultivar Sakiz. Variant plants were sought in this collection and, in the case of some of the cultivars, in their in vitro propagated progenies. Variant plants have been cloned and propagated in the field for several years. Observations were carried out with a larger number of plants for the Violet de Provence cultivar which was used for most of the studies concerning in vitro multiplication and nature of the variants.

\section{Natural multiplication}

Natural vegetative propagation proceeds from the axillary bud of rosette leaves. The leaf shape of propagative organs can be observed if they present expanded leaves, which is the case for offshoots but not for stumps or dried shoots (La Malfa and Foury, 1971).

\section{In vitro multiplication}

In vitro cultures were initiated from apical meristems of growing shoots. Apices with 2 visible primordial leaves measured $0.5 \mathrm{~mm}$ in height at most. The following media were used:

- for development: $1.66 \mathrm{KNO}_{3}$ medium (Tendille and Lecerf, 1974), supplemented with vitamins (Morel and Wetmore, 1951), saccharose $20 \mathrm{~g} / \mathrm{l}$, kinetin $0.1 \mathrm{mg} / \mathrm{l}$, and gibberellic acid $0.1 \mathrm{mg} / \mathrm{l}$;

- for proliferation: Murashige and Skoog medium (1962), supplemented with meso-inositol $100 \mathrm{mg} / \mathrm{l}$, thiamine $0.4 \mathrm{mg} / \mathrm{l}, \mathrm{NaH}_{2} \mathrm{PO}_{4} 85 \mathrm{mg} / \mathrm{l}$, adenine sulfate $40 \mathrm{mg} / \mathrm{l}$, saccharose $30 \mathrm{~g} / \mathrm{l}$, kinetin $0.5 \mathrm{mg} / \mathrm{l}, 2$ ip 0.5 $\mathrm{mg} / \mathrm{l}$, and naphthalene acetic acid (NAA) $0.1 \mathrm{mg} / \mathrm{l}$;

- for rooting: $1.66 \mathrm{KNO}_{3}$ medium, supplemented with vitamins (Morel and Wetmore, 1951), saccharose $30 \mathrm{~g} / \mathrm{l}$, and NAA $0.5 \mathrm{mg} / \mathrm{l}$.

One subculture lasted about 4 weeks, each cluster being divided into a variable number of explants depending on its proliferation rate. Rooting was carried out after subculture numbers that ranged from 3 to 30 , or even more. The first division of the original explant usually took place at the end of the third subculture.

From 1980 to 1989,10 experiments of in vitro multiplication were carried out, each experiment including approximately 10 apical meristems. The normal state of the mother plants was carefully monitored. Difficulties met during micropropagation and rooting made it impossible to obtain the desired sample of 20 plants for each progeny and each duration of in vitro culture.

\section{Ploidy analysis}

Ploidy level was investigated for the 3 variants of Violet de Provence and for the pastel and pastel-bull vari- 
ants of Tudela. Several techniques were used that may be useful to define the ploidy level of the $3 L 1, L 2$ and L3 layers (Arisemi, 1972):

- Pollen observation after aceto-carmin staining. Presence of pollen grains that were larger than the normal haploid grains and a high proportion of aborted grains indicate a possible tetraploid level of the L2 layer. Three plants of each type were observed several times during flowering;

- Chromosome count of root cells with the Feulgen method. Since $2 n=34,68$ chromosomes indicate a tetraploid level of the L3 layer;

- Measurement of stomatal cell length of upper epidermis of leaf and lower epidermis of head bract. A length larger than the normal may indicate a tetraploid level of the L1 layer. Measurements were made on plants issued from several trials. Twenty cells were observed for each of 2-3 samples that were taken from homologous parts of organs having reached their final size. Prints of the stomata on a varnish were measured with an optical microscope;

- Measurement of DNA content in cell nuclei by flow cytometry, either with a Bruker ACR 1400 cytometer (at the Institut Méditerranéen d'Imagerie Médicale), or with a Partec C A II cytometer (at the Gip Prince de Bretagne-biotechnologie at Saint-Pol-de-Léon). Propidium iodide fluorochrome was used in the former, DAPI in the latter. At least 7 samples of leaf blade (1 $\mathrm{cm}^{2}$ ) were analysed for each variant, 3 at different dates with the Brucker cytometer, 4 at 2 dates with the Partec cytometer. Three different plants grown in various places were studied. Two measurements were made for the thread-like roots (sample of $100 \mathrm{mg}$ ).

\section{Field experiments}

Most of the observations were carried out on plants that were put in the field in the beginning of August and were harvested in April-May of the following year. In some trials, plants issued directly from in vitro culture received vernalising temperatures in March, were put in the field in April and were harvested in JulyAugust. Trials were repeated over several years in order to compare yield and earliness of the normal type and its 3 variants.

\section{RESULTS}

\section{Description of the variants}

\section{Results for the Violet de Provence cultivar}

\section{Leaves (fig 1)}

\section{Normal type}

The first leaves of the new rosette are entire, the next leaves are serrated, at first at the base of

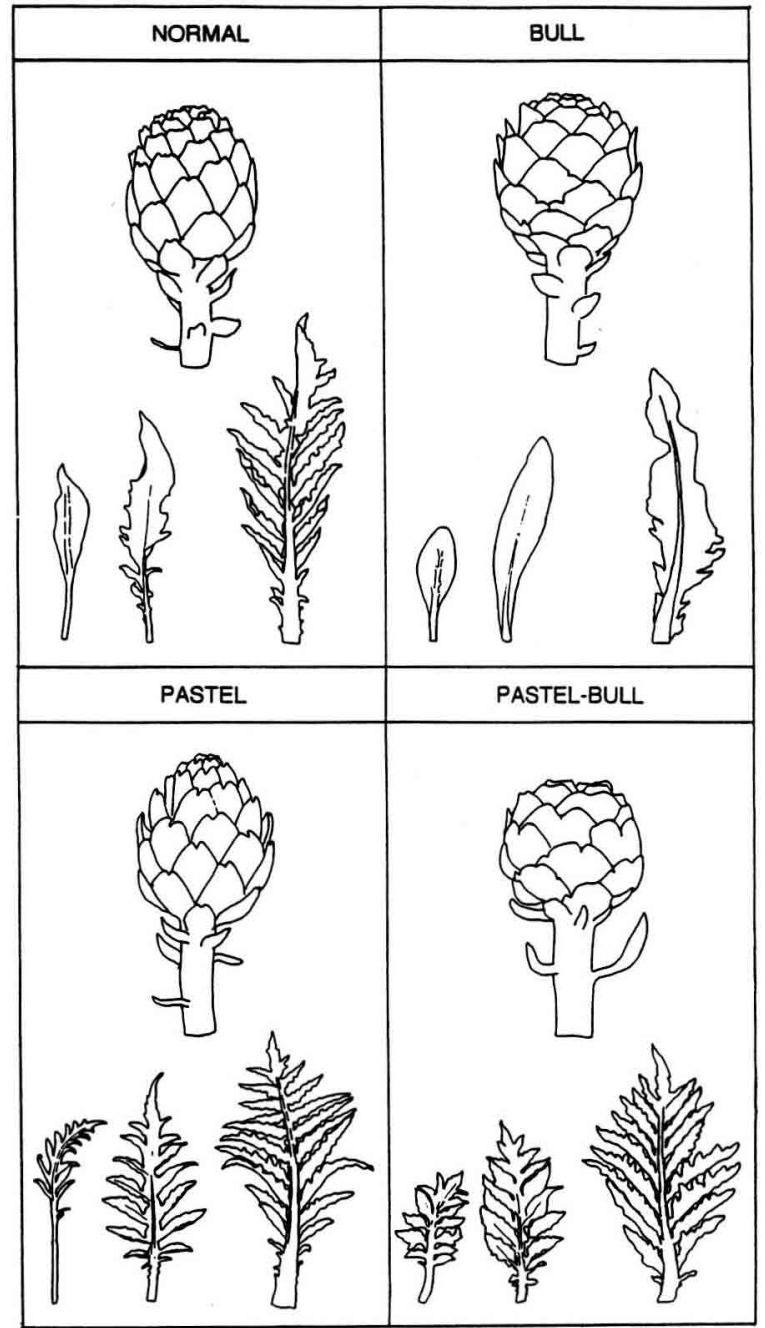

Fig 1. Shapes of leaves and head of the cultivar Violet de Provence (normal) and its 3 variants pastel, bull, and pastelbull (on the left: first leaf of the rosette; on the right: leaf of the fully developed rosette).

the blade, and then more and more deeply all over the margin. Later the leaves become pinnatifid, and finally pinnatisect as the sinuses of the lobes extend nearly to the midrib.

\section{Pastel variant}

Most of the time the first leaves are pennatifid. Lobes of the next leaves are narrower and deeper than those of the normal type and their margins are often more curled. Differences in intensity of the pinnatifid characteristics between normal and pastel plants of the cultivar Violet de Provence are usually very marked for the young rosette leaves, but later become less marked for the deeply divided leaves of developed rosettes. When shoots are planted in the beginning of Au- 
gust, the distinction is obvious until February and becomes less so in March-April. In in vitro culture, normal and pastel plants look alike. After acclimatation, the young rooted plantlets both produce entire leaves. About 2 months later, after the appearance of about the 15th leaf, pastel plants can be identified by their more deeply pinnatifid leaves.

\section{Bull variant}

The first rosette leaves of bull plants are entire and wider than those of the normal type, and the following leaves tend to remain entire; even though they present basal indentations, they never become deeply divided. With the exception of the young stage, bull plants are easily recognized in the field. Moreover, the leaves possess a larger central rib and a significantly thicker blade (124\% of the normal type).

\section{Pastel-bull variant}

The dentation of rosette leaves follows the same evolution as that of the pastel variant. The first leaves are usually pinnatifid, but their shape and the adult leaf shape are clearly distinct from that of the pastel variant with their larger lobes and thicker blade ( $111 \%$ of the normal type). The leaves are often more upright.

\section{Head shape (fig 1)}

\section{Normal type}

The head has an elongated cylindrical or conical shape, the top being slightly open. The bracts overlap tightly, their apical indentation is shallow and presents a more or less rudimentary spine.

\section{Pastel variant}

The head shape is more ovoid and the top is more closed than the normal type head. More convex bracts give a less compact head structure. The bract top indentation is deeper, and the spine has the same size as in the normal type. These heads have a good market quality.

\section{Bull and pastel-bull variants}

The bull variant bracts are shorter and wider than in the normal type, which gives a globular shape to the young head and a wide cylindrical shape to the mature head. This explains the name "bull" or "cat head" used for this type. The bracts are thicker. The heads, which are very different from the normal type, have a low market quality. The characteristics of the pastel-bull variant are nearly the same as those of the bull variant.

\section{Harvest earliness and yield}

The results of one experiment are presented here as they are representative of the average differences observed in several trials between the normal form of Violet de Provence and its 3 variants (table I, fig 2).

\section{Normal type}

Under the climatic conditions of south-east France, the plants of the Violet de Provence cultivar, when put in the field at the beginning of August, are ready for the initial harvesting from 15 March to 15 April depending on the year. When planted in June, their harvest takes place in October-November.

\section{Pastel variant}

Under the same conditions, with the first planting date given above, the pastel variant is ready for harvest 3 weeks later than the normal type. When planted in June, it does not bolt during au-

Table I. Comparison of number of heads per plant and average head weight of the cultivar Violet de Provence and its 3 variants pastel, bull and pastel-bull.

\begin{tabular}{lccc}
\hline & $\begin{array}{c}\text { Number } \\
\text { of plants } \\
\text { examined }\end{array}$ & $\begin{array}{c}\text { Number } \\
\text { of heads } \\
\text { perplant }\end{array}$ & $\begin{array}{c}\text { Average } \\
\text { head } \\
\text { weight }\end{array}$ \\
\hline Normal & 30 & 6.2 & 183 \\
Pastel & 12 & 5.6 & 221 \\
Bull & 6 & 3.0 & 338 \\
Pastel-bull & 6 & 3.6 & 287 \\
\hline
\end{tabular}

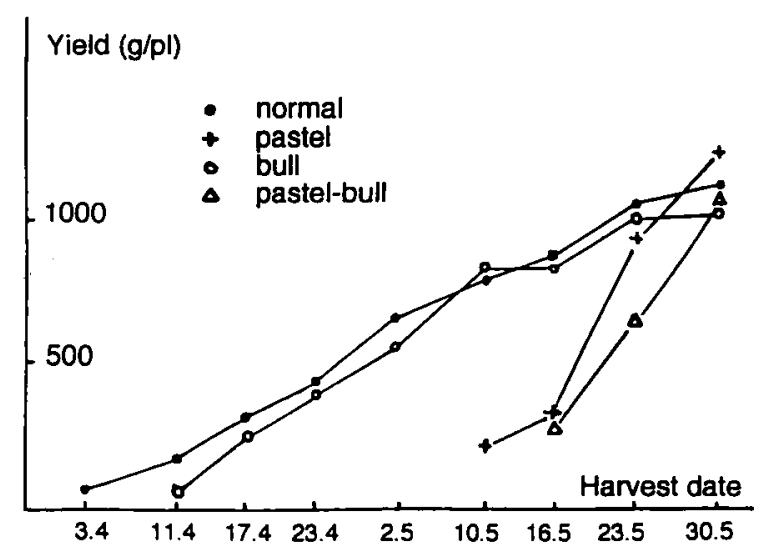

Fig 2. Comparison of earliness and yield of the cultivar Violet de Provence and its 3 variants pastel, bull and pastel-bull. 
tumn. This harvest delay of pastel plants exists both in cultivation of traditional shoots and in cultivation of plants directly obtained from in vitro propagation. Thus, in a field planted with in vitro plants on 21 March, when outdoor temperatures were still low enough to supply the cold requirements for floral induction (Foury, 1987), the first harvest date was 2 July for normal plants and 18 July for pastel plants. The pastel plants are bulkier than normal plants. As their floral induction comes later, they produce a higher number of leaves before bolting. The floral stem is taller (124\% of the normal type). The mean head weight exceeds that of the normal type, while the number of heads per stem is approximately the same. As a result, the yield per stem of the pastel variant is usually higher. However, the normal type can yield more when the early harvest of the first stem is followed by offshoot harvest, which does not occur with the pastel variant.

\section{Bull and pastel-bull variants}

The bull variant has approximately the same earliness as the normal type, while the pastel-bull variant has the same lateness as the pastel variant. Their floral stem have few heads, which leads to a lower yield than the normal type in spite of a higher head weight. Frequently, bull plants present a higher frequency of non-bolting plants than the 3 other types.

\section{Stability}

\section{Pastel variant}

No return of the pastel type to the normal type was observed. Pastel plants were cloned by offshoot propagation and usually 3 offshoots per mother plant were observed. This clonal multiplication was repeated each year, up to 7 times. No normal plant appeared and plants kept all the pastel characteristics described above. An exception to this stability concerned a small number of changes toward the pastel-bull type that occurred among pastel plants recently issued from in vitro culture.

\section{Bull and pastel-bull variants}

Returns of bull plants to the normal type were observed. This can be explained by the fact that when the bull variation appeared, it did not always affect all the plants. Such a chimeral structure was visible in plants which presented the bull traits only in a part of 1 head, or in a part of the floral stem or the rosette leaves. Under these conditions an apparent bull plant could produce both bull and normal offshoots. Nevertheless the bull plants were found to be stabilized after several multiplications; this means that the bull stage had spread into all the organs. The pastelbull variant was found to be stable in these experiments.

\section{Results for other early Mediterranean cultivars}

Pastel variants were studied in the case of 7 other cultivars, Escarot, Liscio sardo precocissimo, Niscemese, Sakiz, Spinoso sardo, Tudela and Violet du Gapeau. For all these cultivars, the pastel variant shows the same characteristics as those described for Violet de Provence. Slight differences in leaf shape of the pastel plants exist depending on the cultivar. For example, with Tudela, the first leaves of the pastel rosette are sometimes as entire as those of the normal plants, but the later leaves always divide much more rapidly. Leaf margins curl markedly in Tudela pastel plants.

Bull and pastel-bull variants were found and observed only in Tudela; they show the same differences in relation to the normal type as those indicated for Violet de Provence.

\section{Frequency of variants}

\section{Results of natural vegetative propagation}

In this study, shoots were taken in August from plants which appeared to be normal throughout the entire cultural cycle. This means that all successive rosettes possessed normal leaves. Most often, offshoots were available, and sometimes stem segments or stumps were used. After shoot plantation, most of the time only one rosette grew in the first year, from the most advanced bud which inhibited the growth of the other buds. Variant frequency was evaluated in 2 ways: firstly the frequency of variant rosettes among the new rosettes, and secondly the frequency of variant offshoots among the offshoots produced by these new normal rosettes. Cumulated results obtained with 3 successive plantations of the collection of 10 cultivars are presented (table II).

Out of 589 shoots, 580 produced a normal rosette, $6(1.1 \%)$ a pastel rosette and $3(0.5 \%)$ a bull rosette. Of the 580 normal rosettes, 13 $(2.2 \%)$ bore both pastel and normal offshoots, at 
Table II. Numbers of normal, pastel and bull plants in the progenies obtained after natural multiplication of early Mediterranean cultivars of globe artichoke.

\begin{tabular}{|c|c|c|c|c|c|}
\hline Cultivar & Total & Normal & Pastel & Bull & Normal $\longrightarrow$ pastel $^{*}$ \\
\hline Escarot & 33 & 32 & 1 & 0 & 2 \\
\hline Liscio sardo precocissimo & 33 & 33 & 0 & 0 & 3 \\
\hline Masedu & 26 & 26 & 0 & 0 & 0 \\
\hline Niscemese & 56 & 56 & 0 & 0 & 0 \\
\hline Sakiz & 30 & 30 & 0 & 0 & 3 \\
\hline Spinoso sardo & 29 & 28 & 1 & 0 & 3 \\
\hline Tudela & 83 & 82 & 0 & 1 & 0 \\
\hline Violet de Corse & 12 & 12 & 0 & 0 & 0 \\
\hline Violet de Provence & 260 & 255 & 3 & 2 & 2 \\
\hline Violet de Gapeau & 27 & 26 & 1 & 0 & 0 \\
\hline Total & 589 & 580 & 6 & 3 & 13 \\
\hline
\end{tabular}

${ }^{*}$ In the progenies, the number of normal plants producing both normal and pastel offshoots.

the average rate of one pastel out of 5.5 offshoots. Thus, over all the offshoots produced by the 580 normal rosettes, the pastel offshoot frequency was $0.4 \%$. Variation to the pastel state took place in 6 cultivars and variation to the bull state in 2 cultivars. Pastel offshoots growing on a specific part of the mother plant rhizome was not observed.

\section{Results of in vitro multiplication}

\section{Experiments with Violet de Provence}

\section{Pastel variant}

The results of 7 experiments of micropropagation are reported in table III. For each experiment, results of all mericlones are given together. Pastel plants occurred in all the experiments.

Table III. Percentage of pastel plants after rooting in 7 experiments of micropropagation of the cultivar Violet de Provence.

\begin{tabular}{cc}
$\begin{array}{c}\text { Total number of } \\
\text { rooted plants }\end{array}$ & $\begin{array}{l}\text { Percentage of } \\
\text { pastel plants }\end{array}$ \\
\hline & \\
140 & 97 \\
100 & 100 \\
22 & 100 \\
118 & 69 \\
104 & 70 \\
98 & 24 \\
51 & 37
\end{tabular}

Out of 633 plants directly obtained from in vitro culture, $456(72 \%)$ were of the pastel type. The frequencies varied with the experiments; some reached $100 \%$.

Percentage of pastel plants increased with subculture number. The results obtained with mericlones for which rooting was carried out several times are reported (fig 3 ).

Change to the pastel state was irreversible. Once the change had taken place, only pastel plants were obtained in subsequent subcultures (table IV).

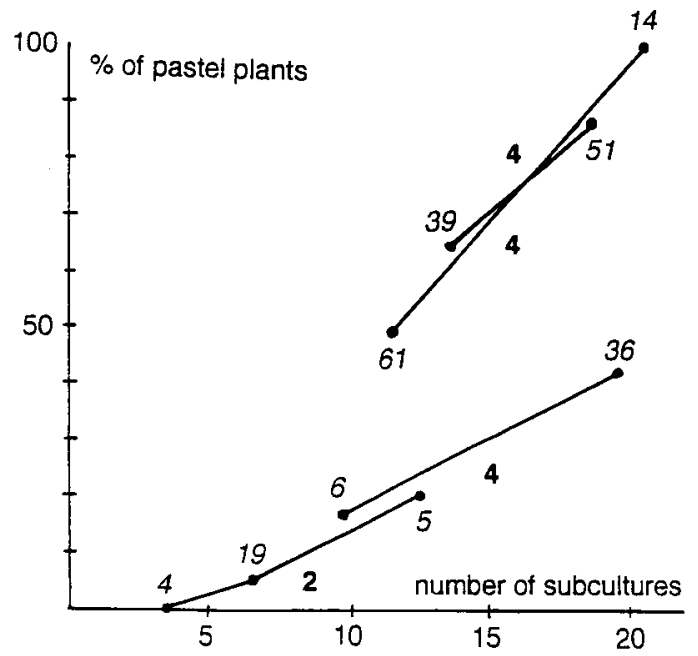

Fig 3. Increase of the percentage of pastel plants when the number of subcultures increases in 4 experiments of micropropagation (cultivar Violet de Provence; in bold: number of mericlones in each experiment; in italics: total number of rooted plants in each experiment for several numbers of subcultures before rooting). 
Table IV. Stability of the pastel variant during 2 experiments of micropropagation of the cultivar Violet de Provence.

Number of mericlones Number of subcultures Average number of rooted plants Percentage of pastel plants per mericlone

\begin{tabular}{cccc}
\hline 2 & $11-12$ & 27 & 100 \\
& about 30 & about 1000 & 100 \\
& & 8 & 100 \\
& $7-8$ & 10 & 100 \\
\hline
\end{tabular}

\section{Other variants}

Out of 773 rooted plants, there were 3 bull variants $(0.4 \%)$, found in 3 different mericlones, and 6 pastel-bull plants, found in 5 mericlones.

\section{Experiments with other early Mediterranean cultivars}

Three cultivars, Liscio sardo precocissimo, Niscemese and Tudela, were propagated in vitro. Pastel plants appeared in rooted progenies, except when the subculture number was low (table V). In Tudela, normal and pastel plants issued from in vitro culture were vegetatively propagated; of 48 plants issued from normal plants one presented a bull sector and of 48 plants issued from pastel plants, 2 were pastel-bull.

\section{Nature of the variants}

\section{Ploidy level}

\section{Pollen size and flower fertility}

Normal and pastel plants were fertile. Their pollen grains with 3 pores were stained with acetocarmin. They produced seeds after self- or allopollination.
In contrast, bull and pastel-bull plants showed a small quantity of pollen at the time of anthesis. About $50 \%$ of the grains extracted from the anthers were aborted and not stained with aceto-carmin. The incompletely stained grains had a very irregular diameter. The fully stained grains were larger $(74 \mu)$ than the normal grains $(62 \mu)$ and often possessed 4 pores instead of 3 . The amount of pollen was insufficient to allow hand pollination in order to study its fertility. The bull and pastel-bull plants, pollinated with viable pollen of a normal type or from other cultivars did not produce seeds, an indication of a low female fertility (table VI). These features are frequent in auto-tetraploid plants, which explains the further analysis of the ploidy level of the variants.

\section{Measurement of DNA content}

Measurement of the DNA content of the nuclei of leaf blade cells by using flow cytometric analysis, revealed 2 levels of ploidy (fig 4). Histograms of normal and pastel types had 1 dominant peak corresponding to the $2 c$ level of DNA. The bull and pastel-bull types showed 1 dominant peak corresponding to the $4 \mathrm{c}$ level of DNA. The leaves of normal and pastel plants were diploid; those of bull and pastel-bull plants were

Table V. Percentages of pastel plants occurring after micropropagation of 3 early Mediterranean cultivars. Influence of the number of subcultures.

Cultivar Number of mericlones Number of subcultures Number of rooted plants Percentage of pastel plants

$\begin{array}{lrcrr}\text { Niscemese } & 5 & 7 & 11 & 9 \\ & 5 & 13-14 & 16 & 69 \\ \text { Tudela } & 5 & 8 & 7 & 0 \\ & 5 & 19 & 27 & 52 \\ \text { Liscio sardo } & 2 & 13 & 5 & 100\end{array}$


Table VI. Seed production of the cultivar Violet de Provence and its 3 variants pastel, bull and pastel-bull.

$\begin{array}{lccc}\text { Female } & \text { Male } & \text { Number } & \text { Number } \\ \text { parent } & \text { parent } & \begin{array}{c}\text { of pollinated } \\ \text { heads }\end{array} & \begin{array}{c}\text { of seeds } \\ \text { perhead }\end{array}\end{array}$

tetraploid. A more detailed analysis of the histograms brought additional findings.

For the Violet de Provence normal type, in general there was a second DNA peak at the 4c level, which was in all cases very much smaller than the 2c peak. Normally this 4c peak corresponds to nuclei at the G2/M state, but it can also indicate a chimeral structure of diploid and tetraploid tissues. This $4 \mathrm{c}$ peak is much higher than in the Violet de Provence pastel type. Whereas this difference between normal and pastel plants was found in 3 independent experiments with Violet de Provence, it did not exist for the Tudela cultivar since in this case pastel plants showed a secondary $4 c$ peak equivalent to the normal type.

For the pastel-bull type of Violet de Provence, in the leaf cell nuclei, there was a second DNA peak at the 2c level that could be high. Moreover, cytometric analysis of the pastel-bull type showed that the thread-like root cell nuclei always showed the 2c DNA level as for normal and pastel types, while they presented the $4 \mathrm{c}$ level for the bull type. This diploid state of roots for the pastel-bull variant was also found in the Tudela cultivar.

\section{Chromosome count in the root cells}

The normal, pastel and pastel-bull types of Violet de Provence and Tudela possessed 34 chromosomes in the root cells. Occasionally some cells with 68 chromosomes were observed in normal and pastel plants. The bull type of Violet de Provence had 68 chromosomes.

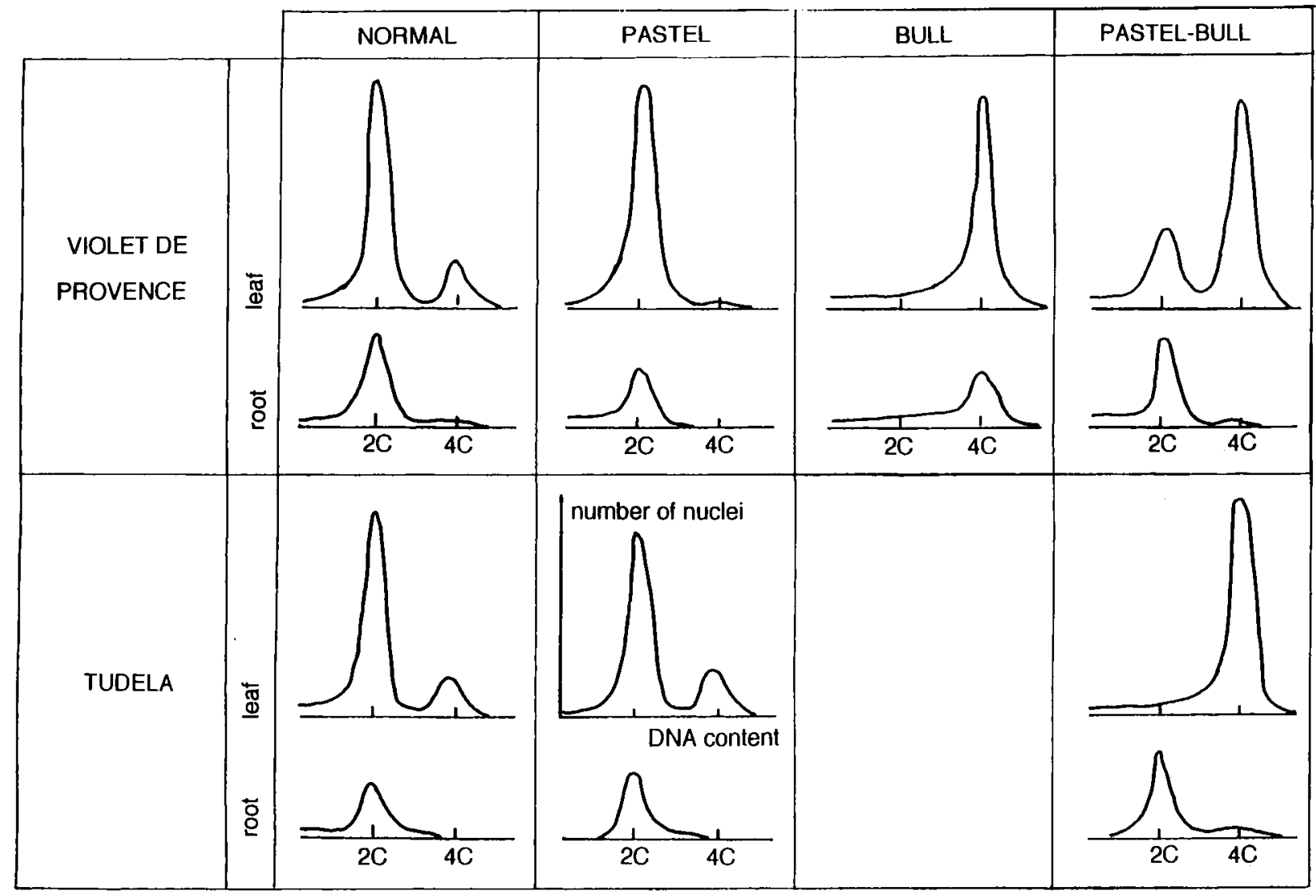

Fig 4. DNA content (logarithmic scale of fluorescence intensity) in leaf blade and root nuclei of the cultivars Violet de Provence and Tudela and their 3 variants : pastel, bull and pastel-bull. 


\section{Stomata cell length}

In Violet de Provence, the same length of stomata cells existed for the normal, bull, and pastelbull types, the stomata being significantly smaller for the pastel type. However, this difference was not established for Tudela (table VII).

\section{Study of the sexual transmission of the distinctive characteristics of normal and pastel plants}

For the Violet de Provence cultivar, the following progenies were studied: a self progeny from normal type (98 plants); a self progeny from pastel plants (120 plants); the F1 hybrid between normal and pastel plant (70 plants); and the reciprocal hybrid (70 plants). No distinction could be made between the different progenies on the basis of leaf shape, which was of the pastel type, bolting earliness and head shape. No plant produced offshoots with entire young leaves even in the self progeny of the normal type, which means that this specific characteristic of the normal type is not heritable.

\section{DISCUSSION AND CONCLUSION}

In the collection of 10 early Mediterranean cultivars grown in the field at the Station d'Amélioration des Plantes Maraîchères after natural multiplication, the occurrence rate of the pastel variation was 0.4 or $1.1 \%$ depending on the method of evaluation, and this variation appeared in 6 out of 10 early Mediterranean cultivars. In the same collection, the bull variation was observed with a rate of $0.5 \%$ and was found in 2 cultivars. The third variation, pastelbull, did not occur in these experiments probably because of the low number of observed pastel plants from which it arises.

The first 2 variants, pastel and bull, are well known in Mediterranean regions. Growers call them "degenerate", "wild" ("silvatici" in Italy), spring-like ("de primavera" in Spain), and they eliminate them in order to maintain bolting earliness and head shape qualities of their cultivars. However, it is not always clear whether these types correspond to stable changes of a nature different from the large environmental variation which is specific to the early Mediterranean cultivars. Thus Jannacone (1967), who worked on the degeneration of the Violetto di Sicilia cultivar, showed that shoots produced at the base of the rhizome had more entire leaves and gave an earlier harvest than shoots taken from the upper part of the rhizome, but he found that these differences were not vegetatively transmitted since the percentage of plants with divided leaves was not linked to this characteristic in the mother plant. It is known that an elongation of the axis of the offshoot gives rise to entire leaves (Pochard, 1964). Such an elongation takes place when offshoots originate from the basal part of the rhizome or when they are treated with gibberellin. Factors delaying the elongation of the axis and slowing primordia formation increase late-

Table VII. Comparison of stomata length of the normal type and the variants of the cultivars Violet de Provence and Tudela.

Stomata length (\% of the normal type)
Number of experiments

Length inferior $\quad$ Length superior
to the normal type $\quad$ to the normal type

\begin{tabular}{|c|c|c|c|c|}
\hline \multicolumn{5}{|c|}{ Violet de Provence } \\
\hline \multirow[t]{2}{*}{ Pastel } & Leaf & 86 & 11 & 0 \\
\hline & Head bract & 79 & 5 & 0 \\
\hline \multirow[t]{2}{*}{ Bull } & Leaf & 101 & 4 & 3 \\
\hline & Head bract & 105 & 1 & 1 \\
\hline \multirow[t]{2}{*}{ Pastel-bull } & Leaf & 93 & 2 & 1 \\
\hline & Head bract & 111 & 0 & 3 \\
\hline \multicolumn{5}{|l|}{ Tudela } \\
\hline \multirow[t]{2}{*}{ Pastel } & Leaf & 99 & 3 & 2 \\
\hline & Head bract & 88 & 2 & 1 \\
\hline
\end{tabular}


ness and division of the leaf blade (Foury, 1987). Thus, heteroblasty is occasionally observed in cultivars which do not belong to the early Mediterranean group.

Other variant types may exist: Foury (1978) indicated 2 variants of Tudela and classed one "madrilenas" as a pastel, and the other as a bull. $\mathrm{He}$ also mentioned 2 other types, "callosinas" and "rebordecidas".

In vitro multiplication leads to the production of a high percentage of pastel plants. This percentage varies among meristem progenies and increases with subculture number. Some of the explants probably change irreversibly from the normal to the pastel state when apical meristems are placed in vitro and with each explant division. The same situation was found in Musa sp for which a theoretical model of the variant frequencies was established (Cote et al, 1992). The procedures of micropropagation are likely to influence the probability of variation in each subculture. In spite of that, it appears that all the laboratories which try to multiply early Mediterranean cultivars observe a pastel invasion of their production. Variation occurs while multiplication proceeds with axillary buds. Adventitious buds seem uncommon, but it is sometimes difficult to be sure of the origin of some new shoots that grow at the bottom of the explant or in a disorganised cluster.

In comparison, bull and pastel-bull frequencies remained low in our experiments. It is not known whether these 2 variants remain stable during subcultures which could occasionally lead to in vitro productions containing a high percentage of these variants. It is impossible to say if the rates of in vitro proliferation are the same for the normal and the 3 variant types.

Data on the nature of the variations were acquired in the case of bull and pastel-bull variants. Both showed the presence of tetraploid tissues. The bull type is a tetraploid form of the normal type. Bull plants appeared among shoots of normal plants, they both bolted early and also produced slightly divided leaves. All the data agree with the homogeneous tetraploid state of bull plants: root cell chromosome number; cytometric DNA analysis of all plant organs; pollen size; and low fertility.

The pastel-bull variant is a diploid-tetraploid chimeral form of the pastel type. It appeared among shoots of pastel plants, they both bolted late and had deeply divided leaves. The pastelbull variant possesses a more complex structure than that shown by the sole study of aerial parts (Pecaut and Foury, 1992). It was found that the roots were diploid. In the leaves, diploid nuclei usually coexisted with a majority of tetraploid nuclei in the case of Violet de Provence, but not in the case of Tudela which showed only tetraploid cells. Pollen size and low fertility indicated a tetraploid level of the L2 layer. This diploidtetraploid chimera appeared 5 times in Violet de Provence and twice in Tudela after micropropagation. Its stability was total during 2-3 natural multiplications from offshoots.

Regarding the pastel variation, no indication was obtained as to its nature. Data showed that the pastel type seems to be a stable form of the cultivar while the normal form is unstable. The former type presents the same characteristics of leaf shape and bolting lateness as the genotypes outside the early Mediterranean group. Preliminary results indicated that the seed progenies of pastel and normal types obtained by selfing or crossing were alike. This means that they must have the same genotype in the L2 layer from which gametes are originated. These progenies did not possess plants presenting the entire leaf shape which is a specific characteristic of the normal type. All the plants seemed to belong to the pastel type. Consequently, the pastel type would represent the true type of the early Mediterranean cultivars, whereas the normal type would be a variant form.

The absence of heritability of the traits of the normal plants could be explained if these plants had a chimeral structure, as was suggested by Pochard et al (1969). As tetraploid tissues existed in bull and pastel-bull variants, such tissues were searched for in the normal type, more precisely in the L1 layer. Cytometric analysis was not carried out successfully because of the difficulties of getting appropriate samples of epidermis. Measurements of stomata length showed a significantly longer size for the normal type than for the pastel type of Violet de Provence. These results are insufficient to establish the ploidy $L 1$ level. Consequently the chimeral structure of the normal type is still hypothetical. Other possible causes of somaclonal variation are not enumerated here (Peschke and Phillips, 1992).

If a chimeral structure of the normal type is the cause of untrue-to-type micropropagation, this defect must be eliminated in a progeny issued from seed which will possess a homogeneous structure. Further experiments are necessary to establish whether clones as early as the normal type can be recovered from such a progeny. To- 
day, in order to produce healthy plants of early Mediterranean cultivars, a practical method consists of discarding the pastel plants after micropropagation. In order to increase the frequency of normal plants, a large number of apex progenies will have to be multiplied simultaneously and the number of subcultures will have to be limited. After rooting, normal plants will be multiplied by natural propagation, which can be accelerated by apex excision under appropriate isolation conditions in order to avoid virus infection.

\section{ACKNOWLEDGMENTS}

The authors thank C Foury for his comments on the manuscript. The cytometric analysis were done by JC Rode and B Longhi at the Institut Mediterranéen d'Imagerie Médicale and by J Corre, JP Le Saint and E Auzas at the Gip Prince de Bretagne-biotechnologie de Saint-Pol-de-Léon.

\section{REFERENCES}

Arisemi T (1964) Colchicine-induced tetraploid and cytochimeral daylilies. $J$ Hered $55,255-261$

Bigot C, Foury C (1984) Multiplication in vitro d'artichaut (Cynara scolymus L) à partir de semences: comparaison au champ de quelques clônes à la lignée dont ils sont issus. agronomie 4, 699-710

Cote FX, Perrier X, Teisson C (1992) Somaclonal variation in Musa sp. Theoretical risks and risk management. INIBAP biotechnology worshop. Costa Rica, CIRAD, Montpellier, France

Foury C (1978) Quelques aspects de I'histoire des variétés d'artichaut (Cynara scolymus L). J Agric Tradit Bot App/ 15 (1), 25-50

Foury C (1987) Quelques aspects du développement de l'artichaut (Cynara scolymus L) issu de semences; analyse plus particulière de la floraison en conditions naturelles. Thèse, Univ $P$ et $M$ Curie, Paris VI, Orsay, France

Foury C, Pochard E, Chambonnet D (1968) Les clônes d'artichaut Violet de Provence sélectionnés par I'INRA et multipliés par le CTIFL. CTIFL - Documents 20, 1-6

Jannacone A (1967) Ricerche sperimentali sulla biologia del carciofo (Cynara scolymus L). Riv Agron 1, 6-13
La Malfa G, Foury C (1971) Aspects de la multiplication végétative de l'artichaut dans le bassin occidental de la Méditerranée. Pép Hort Mar 114, 1929

Morel G, Wetmore RH (1951) Fern callus tissue culture. Am J Bot 38, 141-143

Murashigue T, Skoog F (1962) A revised medium for rapid growth and bioassays with tobacco tissue cultures. Physiol Plant 15, 473-497

Pécaut P (1985) Recherches sur l'artichaut. Rapport d'activité 1983-1984 de la Station d'amélioration des plantes maraîchères d'Avignon, INRA, France, $21-24$

Pécaut P (1991) Recherches sur l'artichaut. Rapport d'activité 1989-1990 de la Station d'amélioration des plantes maraîchères d'Avignon, INRA, France, 9-13

Pécaut P, Foury C (1992) L'artichaut. In: Amélioration des espèces végétales cultivées ( $\mathrm{A}$ Gallais, $\mathrm{H}$ Bannerot, eds) INRA, Paris, France, 460-469

Pécaut $P$, Martin F (1992) Non-conformity of in vitro propagated plants of early Mediterranean varieties of globe artichoke (Cynara scolymus L). Acta Hortic 300, 363-366

Peschke VM, Phillips RL (1992) Genetic implications of somacloncal variation in plants. Adv Genet 30, 41-75

Pochard E (1964) Modifications de la croissance et du développement de l'artichaut provoquées par la gibbérelline. Ann Amélior Plantes 14, 219-225

Pochard E, Foury C, Chambonnet D (1969) II miglioramente genetico del carciofo. Atti del $1^{\circ}$ congresso intern di studi sul carciofo Bari 1967, Minerva medica, Turin, Italy, 117-143

Rossi V, De Paoli G (1990) Micropropagazione per un carciofo di qualita. L'informatore agrario 9, 207209

Saccardo F, Ancora G (1984) II contributo della micropropagazione al miglioramento della coltura del carciofo. In: Giornata su: recenti acquisizioni del miglioramento genetico italiano in orticoltura e floricoltura, Ferrara 9/12/1983, L'informatore agrario, 24-26

Tendille C, Lecerf M (1974) La multiplication végétative de l'asperge (Asparagus officinalis L). Ann Amélior Plantes 24, 269-282

Trigo-Colina I (1981) Étude du comportement clonal de la population d'artichaut Blanca de Espana cultivée dans la vallée de l'Ebre. In: Studi sul carciofo. Atti del $3^{\circ}$ congresso intern di studi sul carciofo Bari 1979, Industria Graphica Laterza, Bari, Italy, $629-638$ 